Tér és Társadalom 18. évf. 2004/1. 59-71. p.

\title{
ADALÉKOK A GAZDASÁGI SZUBURBANIZÁCIÓ KÉRDÉSKÖRÉHEZ
}

\author{
(Additions to the Question of Economic Suburbanisation)
}

\section{KOÓS BÁLINT}

Kulcsszavak:

Magyarország decentralizáció gazdaságiátalakulás szuburbanizáció

A rendszerváltást követöen a magyar gazdaságban is érvényre jutottak a piacgazdaság szigorú törvényei, amelyek intenźv átalakulásra késztették a hazai vállalkozásokat. A megváltozott körülményekhez törtênö alkalmazkodás egyik aspektusa a telephelyek térbeliségének felïlvizsgálata, vagyis a relokáció. A folyamat révén a korábbi erös koncentráció mérséklödik, hiszen a cégek jellemzöen a városkörnyéki településeken keresnek maguknak új telephelyet.

\section{Bevezetés}

Magyarországon az utóbbi években több okból is az érdeklödés középpontjába kerultt a gazdasági tevékenységek térbeli koncentrációjának mérséklődése. A megnövekedett figyelem érthető, hiszen a kérdés jelentős társadalmi-gazdasági csoportok helyzetét befolyásolja. A gazdasági tevékenységek áthelyeződése ugyanis alapjaiban formálja át a kialakult helyzetet: megváltoztathatja az évtizedek alatt kialakult ingázási viszonyokat, a helyi adókon keresztul befolyásolja az érintett önkormányzatok mozgásterét, a kơzszolgáltatások fejlesztésének anyagi alapját. De ide lehet sorolni a munkavállalókat is, sỏt a közszolgáltatások nyújtóit is: a gazdaság igényei nem csupán a tömegkỏzlekedést formálják, de hosszabb távon a szakképzési intézményeket is. Fontos tehát képet alkotnunk arról, hogy a folyamat milyen fơldrajzi kiterjedéssel, intenzitással és szektoriális jellegzetességekkel zajlik.

A folyamat jellemzésére rengeteg fogalom honosodott meg hazánkban, egyebek mellett szokták dekoncentrációnak, szétterülésnek, túlcsordulásnak, kiegyenlítődésnek nevezni. Bár mindegyik kifejezés megragad egy-egy markáns jellemzöt, a továbbiakban mégis inkább a szociológusoktól átvett gazdasági szuburbanizáció (TímárVáradi 2000) kifejezést alkalmazzuk. Ugyanis, megítélésünk szerint e fogalom úgy ragadja meg a folyamat lényegét, hogy nem szúkíti le azt néhány speciális okra vagy esetre, mint teszi azt például a túlcsordulás, bár kétségtelenull magában foglal egy erős földrajzi lehatárolást. Érzékelteti ugyanis, hogy a folyamat korántsem tekinthető általánosnak, inkább csak az urbánus városkörnyéket érinti, miközben a rurális térségek egyáltalán nem, vagy csak kis mértékben kapcsolódnak be a folyamatba.

A nemzetközi szakirodalomban hasonló terminológiai kavalkáddal találkozunk, amiben kétségtelenủl szerepet játszik az egyes diszciplínák eltérő megközelítése is. A közgazdászok előszeretettel használják a dekoncentrációt, illetve diszperziót (Krugman, Porter), az új gazdaságföldrajzi megközelítés hívei (többek között 
Brennan, Hill) inkább a decentralizációt részesítik elönyben (Brennan-Hill 1999). A földrajz, gazdaságföldrajz felöl érkezők ezzel szemben gyakran szétterülésként értelmezik a jelenséget.

A gazdasági aktivitás térbeli dekoncentrációja a fejlett világ valamennyi országában érzékelhető, de intenzitása, időbeli megjelenése komoly eltéréseket mutat. Az Amerikai Egyesült Államokban már az 1950-es években megindult és a hatvanas évekre markáns jelenséggé vált a vállalatok (különösen a feldolgozóipari cégek) kihúzódása a városokból, miközben Európában a folyamat jó tíz éves késéssel: Nagy-Britanniában az 1960-as években, míg a kontinentális Európában inkább csak a hetvenes években jelentkezett (Cheshire-Hay 1989), melynek hatását csak tovább erősítette az 1973-as olajválság. A technikai, technológiai fejlödés, valamint az inputárak drasztikus megváltozása gyors reagálást kényszerített a fejlett világ vállalkozásaira, amelynek egyik eleme volt a telephely elhelyezésének felülvizsgálata.

Magyarországon, miként a többi szocialista államban is, elmaradtak azonban azok a stratégiai döntések, amelyek a megváltozott körülményekhez igazították volna a vállalat müködését. A tervgazdaság keretei közepette, amikor vállalati döntési szabadságról egyáltalán nem lehetett beszélni, nem voltak adottak a feltételek a kényszerü alkalmazkodáshoz: se kellő döntési jogkör, se információ, se pedig megfelelö anyagi háttér nem állt rendelkezésre.

Ezen stratégiai döntések egyike a „,hol múködjön a vállalat”, hiszen a telephely megválasztásával komoly mértékben befolyásolni lehet a vállalat költségeit, esetenként még az árbevételét is. Ez a kérdés természetesen csak a tényleges gazdálkodási szabadság létrejöttével kapott figyelmet, ami aztán egy igen intenzív relokációs hullámot eredményezett a rendszerváltást követỏen. Az a folyamat, amely a fejlett gazdaságokban közel két évtized alatt zajlott le, hazánkban jóval intenzívebben folyt és folyik még ma is, hiszen még korántsem állíthatjuk, hogy befejeződött volna a tevékenységek ,térbeli racionalizálása”. A magyar gazdaságnak a telephely választás területén közel négy évtizednyi (technologiai, infrastrukturális, szemléleti) fejlödéshez kell rövid idön belül alkalmazkodnia, ha javítani akarja nemzetközi versenyképességét.

\section{Elméleti keretek}

A vállalkozások térbeli elhelyezkedése évszázadok óta foglalkoztatja mind a tudományos, mind pedig az üzleti élet szereplöit. A klasszikus telephelyelméletek (Thünen, Weber, Lösch) alapvetéseit, miszerint racionális gazdálkodót és tökéletes informáltságot tételeztek fel, ugyan számos irányból támadták, ám mégis alkalmasnak bizonyultak mind a tudományos élet, mind pedig a napi (gazdasági) döntési helyzetekben. A döntés kritériumává ugyanis a költségminimalizálást emelték, amely számszerüsíthető és alkalmas a versengő alternatívák összevetésére is. Söt az elmélet alapján megmagyarázhatóvá váltak a gazdasági tér „egyenetlenségei” is bizonyos ágazatok területi koncentrációja levezethetövé vált a költségviszonyokból. Az 1950-es évektől kezdődően azonban érzékelhetően megváltozott a gazdaság 
térbeli elhelyezkedése, a vállalatok látványos költözködésbe kezdtek, megkérdöjelezve ezzel az addigi elméletek érvényességét. A tudományos világ válasza nem késett soká (Isard), hamarosan megjelentek azok a publikációk, amelyek az új helyzethez igazították a régi elméleteket, a költségviszonyok megváitozása ugyanis alapvetô változásokat idézett elö.

Tekintsük át, milyen tényezök hatására döntenek a vállalkozások a relokáció mellett. (A tényezök és hatásaik számbavételekor nagyban támaszkodtunk Natalie Cohen 2000-ben megjelent Business Location Deciosion-Making and Cities: Bringing Companies Back címú kutatási eredményeire.)

A szervezeti változás gyakran jár együtt a cég tevékenységének földrajzi értelemben vett racionalizálásával. Különösen hangsúlyossá vált ez a kérdés a vállalati életben drasztikusan megugrott felvásárlások és összeolvadások (M\&A üzletek) következtében, hiszen a korábban független szervezetek összevonása lehetőséget teremt a szinergikus hatások maximális kihasználására, a szervezeti ellenállás megtörésére. Különösen jelentös a változás, ha egy tradicionális családi tulajdonú vállalkozás kerül „eladósorba”, mivel e vállalatcsoport tagjai jellemzően erősen kötődnek az alapítás helyéhez.

A szervezeti változás természetesen nem köthetỏ csupán a tulajdonosi kör átalakulásához, számos más hatás is a szervezeti változás és ezzel a telephelyváltás felé tereli a szervezetet. E hatások közül feltétlenül ki kell emelni az utóbbi három évtized egyre élesedó piaci versengését, amely drámai mértékben átalakította a vállalatok felépítéséröl alkotott képet. A különböző versengö menedzsment-tanok divathullámait követve a szervezetek jószerével permanens átalakulás állapotában vannak, amelynek a hátterében a külső környezet dinamikus változása áll. Gyakorlatilag, amire a szervezet alkalmazkodik egy helyzethez, addigra a környezet újabb változása miatt ismét alkalmazkodásra kényszerül.

A különböző szervezeti átalakítások földrajzi kihatásait nem szabad alábecsülni. A szervezeti hierarchia lelapítása (Carlzon 1985) nem csupán a szervezeti szintek számát csökkentette, de az ideálisnak tekintett épület képét is megváltoztatta. Elötérbe kerültek azok a nagy alapterületủ, „lapos” irodák, amelyek már kialakításuknál fogva is jobb átláthatóságot, kisebb széttagoltságot képviselnek a több emeleten szétszórt irodákkal szemben. Ez a vezetői szemlélet a belvárosi felhőkarcolók irodáival szemben inkább a külvárosi, szuburbán irodákat preferálja.

A technológiai fejlödés hatása az optimális telephely kiválasztására triviálisnak tekinthető: a vasútvonalak kiépítése tette lehetővé az első nagy ipari vállalkozások létrejöttét. Iparfejlesztő hatását mi sem mutatja jobban, mint hogy a budapesti gyáripar is jellemzően a körvasút menti területeken telepedett meg (Ferencváros, Újpest, Kispest), ott fejlődött naggyá. A közlekedési lehetőségek fejlödésén túlmenően a kommunikációs technikák fejlődése is nagy hatással bír a földrajzi elhelyezkedésre. A telefonellátottság javulásával vált lehetôvé a vállalati funkciók elkülönítése, melynek hatására a vállalatvezetés a belvárosi irodákba költözött, a termelés pedig elöbb a városszéli telephelyre, majd a későbbiekben a rurális térségekbe húzódott ki (urban-rural shift). 
A kommunikációs költségek csökkenése, az internet, az e-mail jelentette forradalmi változás új dimenziókba helyezte a telephelyválasztás kérdését, lehetővé vált ugyanis a vállalati funkciók térbeli elhelyezkedésének globális optimalizálása. Harminc éve még elképzelhetetlen lett volna egy olyan szervezet, amelynek központja New Yorkban van, az ,irodai” funkciók egy texasi kisvárosban, a termelés pedig Bulgáriában, Vietnámban és Brazíliában.

A telephely racionális elhelyezését komoly mértékben képes befolyásolni a kormányzati tevékenység, mivel alapjaiban képes megváltoztatni a költségviszonyokat. A kormányzat szabályozási aktivitása a különbözö deregulációs, liberalizációs politikák következtében mélyreható változásokat generált az lizleti életben. Elég itt csupán a telekommunikációs, illetve a légiközlekedési piac felszabadítására utalni, a piaci verseny hatására mindkét területen látványosan zuhantak az árak, megváltoztatva ezzel a költségviszonyokat, új helyszíneket értékelve fel.

A szabályozási tevékenység ennél direktebb módon is kifejtheti hatását, elegendő, ha megszigorítják az építési előírásokat, a környezetvédelmi szabályokat, vagy korlátozzák a közlekedést, például súlykorlátozást vezetve be.

A kormányzat nem csupán regulátorként, hanem vásárlóként is komoly befolyást gyakorol a vállalati életre. A nagy állami infrastrukturális beruházások (autópálya, repülőtér, híd, újabban nagýsebességủ vasútvonal) építése a közlekedési költségek módosítása révén gyakorol befolyást a gazdálkodókra.

\section{A hazai helyzet bemutatása}

A rendszerváltást követöen, a gazdasági szabadság megteremtésével létrejöttek azok az alapvető feltételek, amelyek teret és lehetóséget teremtettek a hatékonyabb gazdálkodásnak. A vállalkozási szabadság megteremtésével látványos növekedésnek indult a gazdálkodó szervezetek száma, kezdetben fỏként a több telephelyes állami vállalatok felbomlásával, illetve privatizációjával, késöbb jóval inkább az új alapítású vállalkozások révén. A vállalkozások száma alapján azonban erős területi koncentrációt fedezhetünk fel, a kettős könyvvitelt vezetö vállalkozások közel fele Budapesten került bejegyzésre. Az utóbbi években ugyanakkor felfedezhetô, hogy a korábbi erős koncentráció oldódóban van, ha kis mértékben is, de érzékelhetö az elmozdulás a kiegyenlítődés felé.

A folyamat két forrásból táplálkozik, egyrészt nagy számban jönnek létre új vállalkozások, másrészt pedig a meglévő vállalkozások is „mozognak a térben”, áthelyezik működésük helyszínét a számukra jobb feltételeket nyújtó területekre. Napi tapasztalat, hogy a fövárosi agglomerációban gomba módra szaporodnak az iparilogisztikai-kereskedelmi parkok, látványosan példázva a dekoncentrációt. De jogosan merül fel a kérdés, hogy ez a folyamat csak a fövárost érinti, vagy a jelenség országosnak ítélhető? Milyen irányú ez a vándorlás? Milyen vállalkozások döntenek müködésük áthelyezése mellett?

A kérdéseket sokáig lehetne sorolni, de világosan kell látnunk, hogy számos tényezỏ nehezíti a tisztánlátást. Legfontosabb, hogy a nyilvános adatbázisok csak a vállal- 
kozások székhelyadatait tartják nyilván, de azt már nem, hogy ténylegesen hol van a vállalatvezetés, és akkor még nem is szóltunk a különböző tulajdonosi összefonódásokról, az azonos tulajdonosi kör által müködtetett vállalatokról, vállalatcsoportokról.

A KSH által negyedévente megjelentetett Cég-Kód-Tár adatbázisra támaszkodva mégis nyerhetünk valamiféle képet a vállalkozások térbeli mozgásáról, ugyanis nyomon követhetők a bejelentett székhelyt érintő változások. Ezen adatok jelentőségét túlbecsülni nem szabad, hiszen a vállalkozás székhelyének megváltoztatása inkább csak papírmunkát igényel, mintsem komoly anyagi, időbeli ráfordítást, ebböl adódóan élhetünk a gyanúperrel, hogy ezen átjelentkezések egy része csupán a hivatalos nyilvántartások szerint valósul meg, a valóságban nem. Másrészről viszont az is kétségtelen, hogy a tényleges kiköltözéseket maradéktalanul tartalmazza az adatbázis.

Lássuk mindezek után, hogy milyen megállapításokat tehetünk a gazdasági társaságok relokációs tevékenységéröl egy hároméves időszak (1999-2001) alapján. Az említett adatbázis adatai alapján hazánkban 282713 olyan vállalkozás volt, amely mind 1999-ben, mind 2001-ben müködött. A vizsgált idöszakban 19858 vállalkozás jelentette át székhelyét, ami azt jelenti, hogy minden tizennegyedik vállalkozás (7,02\%) költözésre szánta el magát.

\author{
1. ÁBRA \\ Megyei szintre számitott vándorlási egyenleg, 1999-2001 \\ (Migration Balance in County Level, 1999-2001)
}

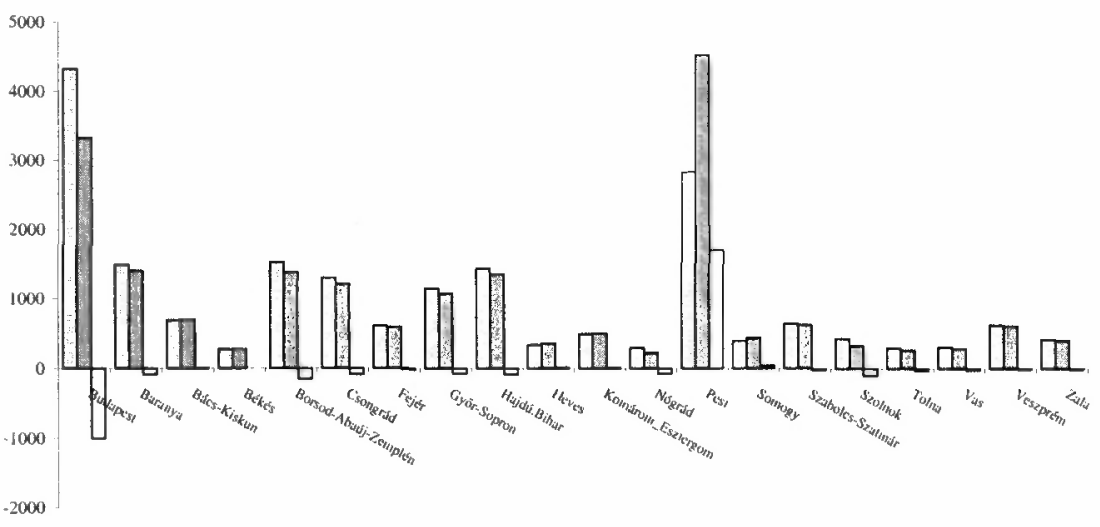

$\square$ Elköltoozző

Forrás: KSH Cég-Kód-Tár 1999/1; 2001/3.

$\mathrm{Az}$ 1. ábra jól érzékelteti, hogy bár valamennyi megyében tapasztalható relokációs tevékenység, mélyreható változást csupán Budapest és Pest megye tekintetében fedezhetünk fel. Míg a többi megye esetében a vándorlási egyenleg értéke -149 (Borsod-Abaúj-Zemplén) és +8 (Komárom-Esztergom) között ingadozik, vagyis azt mondhatjuk, hogy a cégek költözési hajlandósága alacsony, a központi régió 
esetében kifejezetten magas értékkel találkozhatunk. Budapest a vándorlási kedv vesztesének (-1001), míg Pest megye a folyamat nyertesének (+1696) tekinthetö.

Elhamarkodott következtetés lenne a fenti eredmények alapján azt állítani, hogy a gazdasági szuburbanizáció kizárólag a fővárosi agglomeráció esetében érzékelhető. Amennyiben ugyanis települési szinten vizsgáljuk meg a vállalkozások térbeli mozgását, érdekes eredményre jutunk.

A nagyobb lélekszámú városok közvetlen közelében szinte minden esetben találni olyan települést, amely jelentős számú vállalkozást volt képes letelepedésre bírni. Csupán a példa kedvéért nevezzünk meg néhányat közülük! Ide sorolhatjuk a Pécs melletti Kozármislenyt, a Győrrel szomszédos Abdát és Györújbarátot, illetve Szeged mellöl Szatymazt, Sándorfalvát és Deszket. Budapest esetében felesleges lenne a felsorolás, mert jószerével Pest megye valamennyi települését meg lehetne nevezni (2. ábra).

\section{2. ÁBRA}

A beköltözö cégek száma

(The Number of Companies Moved to the Settlements)

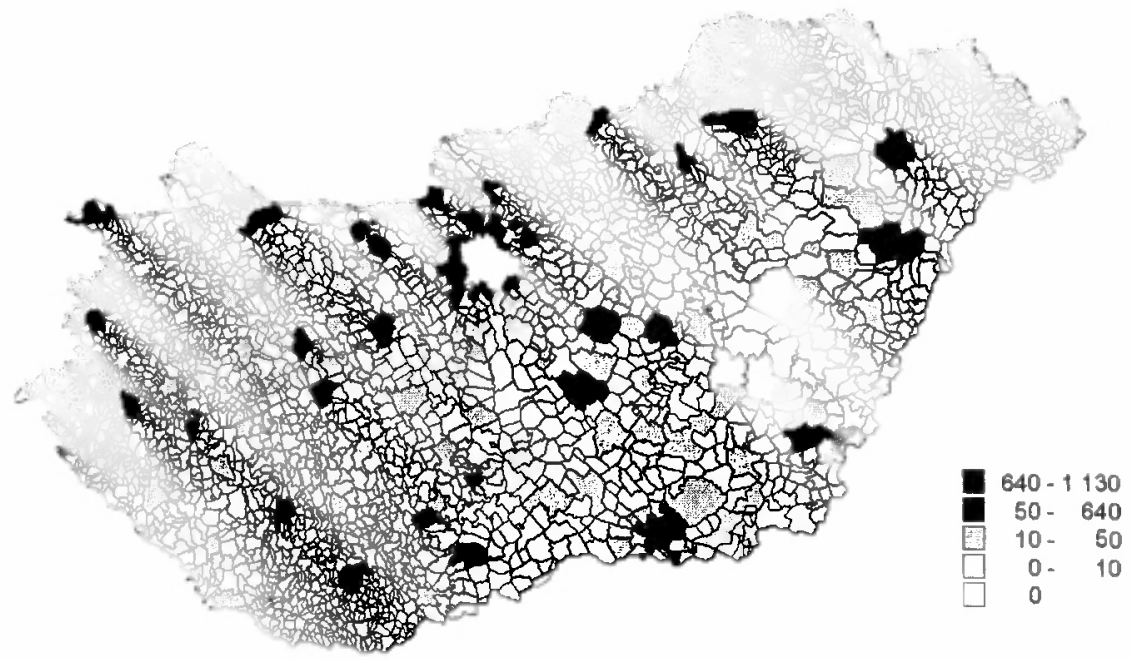

Forrás: KSH Cég-Kód-Tár 1999/1; $2001 / 3$.

A települési adatsorokat megvizsgálva megállapíthatjuk, hogy a nagy lélekszámú és/vagy jó közlekedési helyzetủ, országos föút mentén elterülő települések voltak a leginkább képesek arra, hogy gazdasági bázisukat betelepülő cégekkel erősítsék meg. Különösen látványos a fövárosból kiinduló országos föutak mentén elhelyezkedö városok, falvak gyarapodása. A 2-es, 11 -es, 10-es, 1-es, 6-os, 5-ös, 4-es, 3-as számú föutak helyenként 50-60 kilométeres „csápokat” formálnak, mintegy vizuálisan is igazolva az országos fỏutak gazdasági tengely szerepét. A fỏvárosi agglomeráción kívül a 8-as (Székesfehérvár-Veszprém-Ajka), a 21 -es (Hatvan-Pásztó- 
Salgótarján), valamint Debrecen környékén a 4-es és a 35-ös számú út egy részén fedezhetünk fel hasonló mértékủ koncentrálódást.

Jogosan merül fel ezek után a kérdés, hogy honnan érkeznek a betelepülö cégek ezekre a kitüntetett helyszínekre. Az adatbázisból nyert válasz nem mond ellent sem a közvélekedésnek, sem pedig a vállalkozói interjúk révén nyert tapasztalatoknak: nagyon ritka a gyökeres váltás, sokkal jellemzöbb, hogy a vállalat a már ismert piacon kíván jobb pozícióba kerülni, nem akar egy teljesen ismeretlen világban elölról kezdeni mindent. Ennek alátámasztására egyetlen példa: a vizsgált időszakban Baranya megyében 1484 cég döntött a költözés mellett, közülük 1215 (82\%) maradt a megyehatárokon belül, s közel 70\%-uk (1031) az eredeti kistérségen belül keresett új székhelyet magának (3. ábra).

\section{3. ÁBRA}

Kistérségi szintre számitott vándorlási egyenleg (1999-2001)

(Migration Balance in Micro Regional Level, 1999-2001)

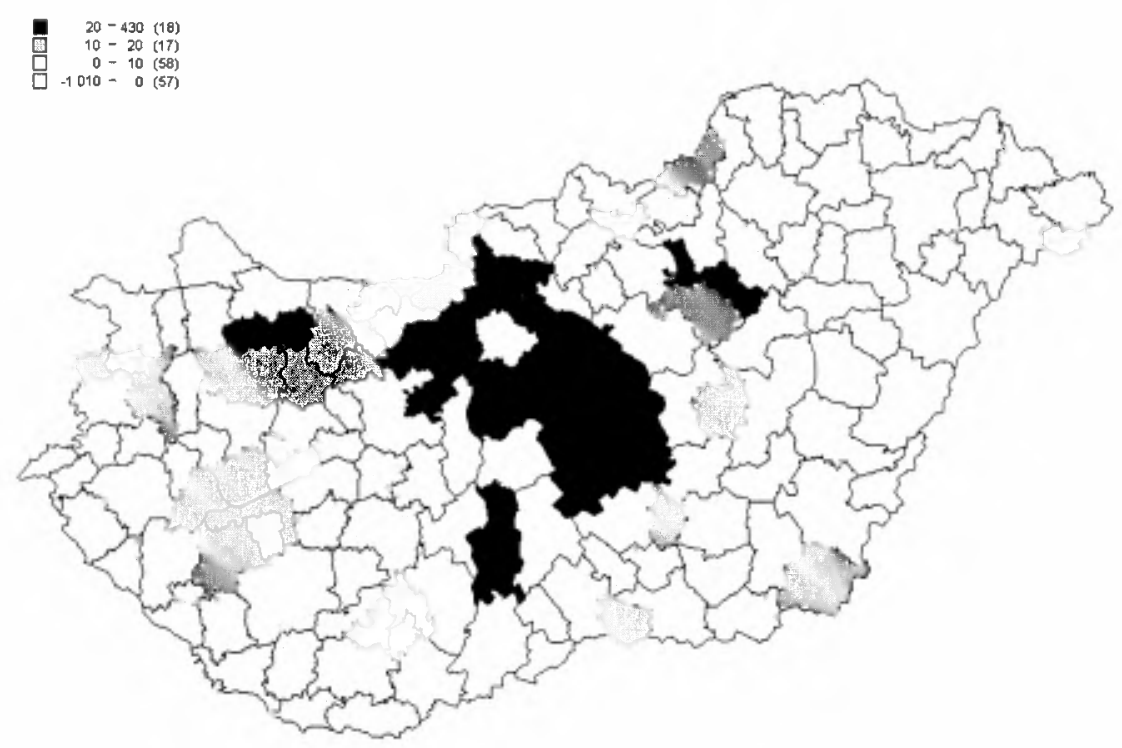

Forrás: KSH Cég-Kód-Tár, 1999/1; 2001/3.

A kis távolságon belüli költözést nem csupán információs okok (fogyasztói, beszállítói bizalom), hanem praktikus tényezők is magyarázzák. A relokációt ugyanis mindig az adott alkalmazotti körrel kell lebonyolítani, mivel egyetlen cég sem engedheti meg magának, hogy az új alkalmazottak felvételéig, betanításáig ne üzemeljen. Ebből adódik, hogy az új hely kiválasztásánál figyelembe kell venni a munkatársak ingázási hajlandóságát is. Az Egyesült Államokban, ahol jóval mobilabb a munkaerő, sokkal gyakoribb a nagy távolságot jelentö relokáció, de még ott is tipikusnak nevezhetö, hogy a munkatársak alig tizede követte a céget, amikor az 300 mérfölddel 
keletre költözött. Nem véletlen, hogy a jó közlekedési helyzetü települések voltak a leginkább képesek a költöző cégek letelepítésére, nem csupán a szükséges teherforgalom, de a létfontosságú ingázás tömegközlekedési feltételei is ott adottak.

Vizsgáljuk meg ezek után, hogy milyen tendenciák jellemzik a fövárosi agglomerációt a gazdasági szuburbanizáció tekintetében. Mint arra már korábban kitértünk, Pest megye nagy számban volt képes vállalkozásokat becsábítani - és ami sokkal fontosabb - a betelepülỏ vállalkozások száma jelentös mértékben meghaladta az elköltözö cégek számát, ily módon pozitív vándorlási egyenleget biztosítva a vizsgált időszakra (4. ábra).

\section{4. ÁBRA}

Pest megyei településekre beköltözö cégek száma (The Number of Companies Moved to the Settlements of Pest County)
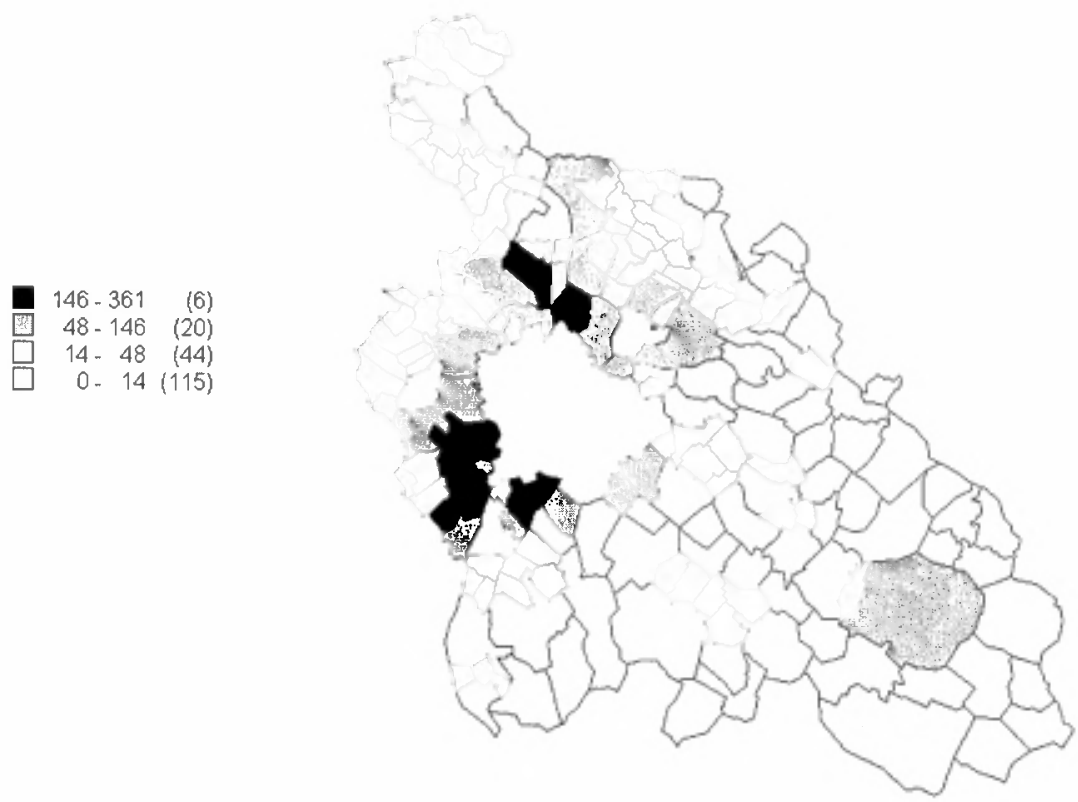

Forrás: KSH Cég-Kód-Tár, 1999/1; 2001/3.

A megyében letelepedỏ vállalkozások kétharmada a fövárosból érkezik, ami meghatározó hatást gyakorol a térség gazdaságára (5. ábra). A megyén belüli relokáció mértéke nem tekinthető magasnak, mind a népesség, mind pedig a helyben lévő vállalkozások számához viszonyítva közel átlagos a mobilitás. A többi megyével összevetve némileg kedvezőbb Pest megye helyzete, hiszen velük szemben is pozitív vándorlási egyenleget tud felmutatni, ami kétséget kizáróan jelzi a terület gazdasági vonzerejét. 


\section{5. ÁBRA}

A Pest megyében letelepedö vállalkozások száma és megoszlása a korábbi székhely alapján

(The Number and the Distribution of Companies Settled Down in Pest County by the Previous Centre)

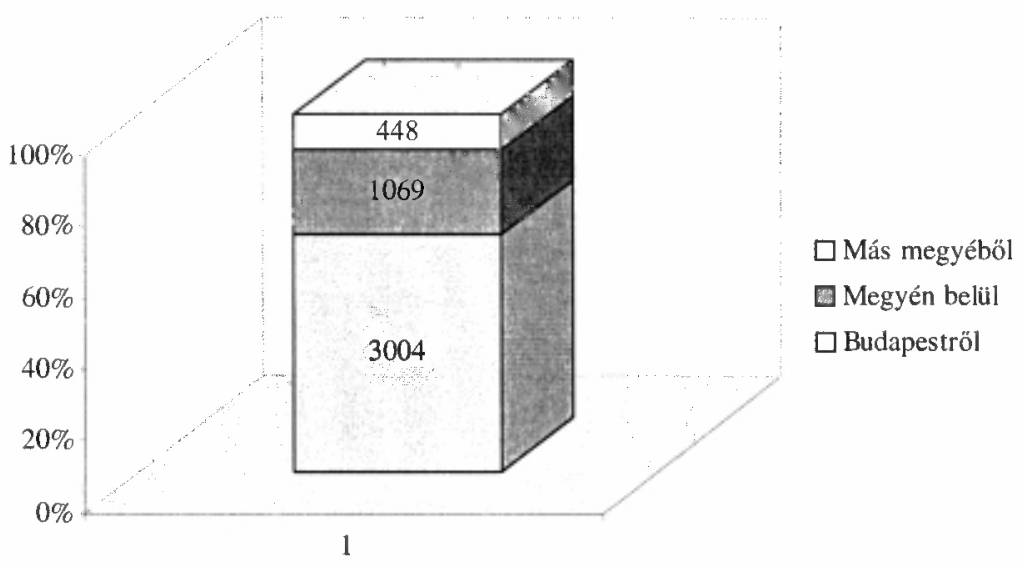

Forrás: KSH Cég-Kód-Tár, 1999/1; 2001/3.

A Budapestrỏl elköltöző vállalkozások telephelyválasztása tekintetében azt lehet mondani, hogy a legfontosabb tényezö a fővárostól való távolság, és csak másodsorban számít a település lélekszáma és a jó megközelíthetőség. De ha ez a három tényező egy irányba mutat, vagyis a fỏváros közvetlen közelében terül el, jó közlekedési kapcsolatokkal és viszonylag nagy lélekszámmal rendelkezik, akkor a település bizton számíthat a kiköltöző cégek iparüzési adójára. Nem meglepő, hogy a vizsgált időszakban Szentendre, Budaörs, Törökbálint, Érd és Szigetszentmiklós volt képes a fövárosi cégeket legnagyobb számban áttelepülésre bírni (4. ábra). Csupán az elmúlt három éves időszakban olyan neves cégek tették át székhelyüket Budaörsre, mint a Vivendi (telekommunikáció), a Tesco (kereskedelem), valamint a gyógyszeriparban tevékenykedő Roche.

A gazdasági társaságok mozgásának számszaki regisztrálására, bizonyos megkötésekkel, alkalmasak a statisztikai adatok, azonban a folyamat mélyebb rétegeinek feltárása csak a szereplök jobb megismerése révén lehetséges. Ennek érdekében az elmúlt három évben ötvennél is több interjút készítettük a fövárosból az agglomerációba kiköltözö cégek vezetőivel, hogy megismerjük a folyamat mozgatórugóit, visszásságait. Az interjúkat 1999 februárja és 2002 augusztusa között folytattuk le a fövárosi agglomerációban, elsősorban az M0 körgyürü megépült szakasza mentén (Biatorbágytól Gyálig). 
A terepmunka tapasztalatai alapján kísérletet tehetünk a vándorló cégek jellemzésére. "Öntörvényüek" - ide sorolhatók azok a fejlödőképes hazai kisvállalatok, amelyek valamilyen kényszerító körülmény hatására - ez a leggyakrabban az, hogy kinőtték a korábbi telephelyet, de elöfordul, hogy jogszabályi változások kényszerítô hatására - keresnek új helyszínt maguknak (szigorodó emissziós normák, súlykorlátozás az utakon). Általában nagyon körültekintőek, széles körben tájékozódnak a lehetőségekről, nem félnek egyedül belevágni az új telephely kialakításába, még akkor sem, ha ez komoly szervezési, engedélyeztetési procedúrát jelent (például földátminősítés, közmúvesítés). A döntéseket jellemzöen egyetlen személy hozza meg, aki általában maga az alapító, a meghatározó tulajdonos és egyben az ügyvezető is. A legfontosabb döntési szempont a nagy növekedési potenciál (vagyis nagy terület) biztosítása, a jó megközelíthetőség, ami általában azt jelenti, hogy az ügyvezető fél órán belül beérkezzen, valamint az, hogy a meglévő munkavállalói kör számára biztosítható legyen a napi beutazás. (Elönyös a jó tömegközlekedés, de arra is találni példát, hogy céges autóbusz gyüjti be az alkalmazottakat.) A szállítóivevői kapcsolatok megőrzése, fejlesztése nem fogalmazódik meg általában döntési szempontként, ugyanakkor jellemzöen a költözés rövid távolságot jelent, ami biztosítja a kialakult kapcsolatok megtartását, sőt akár szorosabbra fúzését is. Ahogy azt egy interjúalany megfogalmazta: „,Mi voltunk itt, ebben a faluban az első fecskék de minket újak is követnek, mert mi a beszállítóinkat, alvállalkozóinkat is ide csábítjuk." (Gáspár János - Engofer Kft. Felsőpárkány)

„Kereskedök" - ebbe a csoportba azokat a külföldi tőkével müködő kis és nagykereskedelmi vállalkozásokat soroltuk, akik a rendszerváltás után, minimális kockázatot vállalva Budapesten nyitottak egy pár fös vállalkozást a piac tesztelésére. A jellemzően bérelt irodában-raktárban dolgozó vállalkozások a hazai piac kiismerése után, a pozitív visszajelzések hatására komolyabb beruházásokra szánták el magukat - s ekkor már a klasszikus telephelyválasztási elveknek megfelelően városkörnyéki ingatlanokba költöztek ki. A döntéseket jellemzóen nem a hazai, hanem az anyacég vezetöi hozták meg - helyenként komoly szervezeti ellenállást váltva ki a magyar alkalmazottak körében.

Ahogyan egy 1995-ben Törökbálintra kiköltözött papír-nagykereskedelmi cég gazdasági igazgatója fogalmazott: az osztrák cégvezetés hozta meg a döntést, hogy ki kell költözni a fövárosból, ezért aztán Budapest határában, szó szerint egy kukoricaföldön láttak neki az új raktár-iroda komplexum felépítésének. Egyöntetű volt a vélemény a cégen belül, hogy ezzel a vállalat alárta a saját halálos ítéletét - a vevők nem lesznek hajlandók kimenni a cég után, és kérdéses, hogy a kereskedők vállaljáke a hosszabb utazást. A költözés ellen szólt, hogy a III. kerületben, ahol a cég akkoriban múködött, 20\%-kal olcsóbban lehetett volna egy jó állapotú, korszerü raktárcsarnokot vásárolni, mintsem egy újat felépíteni. A döntés azonban Bécsben született meg, a helyi költségviszonyok figyelmen kívül hagyásával.

Ez a vállalati kör preferálja a jó megközelíthetóséget, és kisebb hangsúlyt fektet az alacsony ingatlanárakra, így aztán nagy számban találkozni velük a M0, M1, M7 autópálya melletti ipari-logisztikai parkokban. 
A „kamionosok" csoportjába a közúti teherszállítással foglalkozó, illetve komoly teherforgalmat bonyolító vállalkozások: fuvarozók, logisztikai szolgáltatók sorolhatók. Számukat tekintve kifejezetten szük csoportot alkotnak, de gazdasági jelentöségüket tekintve meghatározóak lehetnek az adott település tekintetében. Több száz föt foglalkoztat például a biatorbágyi Rynart Transport, az üllöi Tibbett\&Britten, vagy a szintén Ưllőn müködő $\mathrm{K}$-Sped $\mathrm{Kft}$. Az országos elosztási feladatokat ellátó vállalatok számára rendkívül fontos a központi raktár helyének megválasztása, hiszen a hatalmas futásteljesítményt produkáló jármúállomány esetében 5-10 kilométeres többlettávolság is komoly költségeket jelent. A kiköltöző cégek között szinte kizárólag külföldi tulajdonú, nemzetközi porondon is komoly hírnevet szerzett vállalkozással találkozunk, a hazai cégek körében alig-alig találni példát a relokációra. (Pontosabban településen belüli költözések dominálnak, példaként hozható fel a Masped esete, hiszen ők a belvárosi irodából egy Váci utcai, bérelt irodába költöztek át.)

Itt kell megemlíteni, hogy a komoly áruforgalmat ugyan nem bonyolító, de a kamionok kiszolgálásával, szervízelésével, forgalmazásával foglalkozó cégek is hasonló relokációs mintákat követnek: vagyis döntő az autópályák és az M0 gyors elérhetősége, miközben az ingatlan ára csekély súllyal esik latba. Jellemzö, hogy ezeket a logisztikai parkokat erre specializálódott ingatlanfejlesztő cégek (AIG/Lincoln, Crow Holding, Gronmijk stb.) üzemeltetik, gyakran eleve bérleménynek épített raktárcsarnokokkal, kiszolgáló létesítményekkel. Érdekes fejlemény, hogy ebben a szférában a relokáció második hulláma is megindult: míg az elsö években Törökbálint-Budaörs volt a felkapott helyszín, az utóbbi időben bizonyos kihúzódás kezdödött meg e településekröl a távolabbi, olcsóbb és kevésbé irodai-kereskedelmi jellegủ települések felé: kitüntetett célterületté vált Biatorbágy és Dunaharaszti. Említésre méltó az is, hogy az utóbbi években egyre több országos hatókörú kereskedelmi lánc (CBA, REWE, Penny Market) helyezi központi raktárbázisát Alsónémedi északi iparterületére, ami egyrészt az M0-körgyürủ közvetlen közelében terül el, másrészt pedig szinte az ország földrajzi középpontját jeleníti meg.

A „számlások” csoportja a létszámát tekintve a legnagyobb, de gazdasági ereje, jelentősége messze elmarad a korábban említett csoportokhoz képest. A megyében letelepedő vállalkozások kétharmadának egyáltalán nincs, vagy csupán egyetlen alkalmazottja van, $70 \%$-ának pedig árbevétele nem éri el a 20 millió forintot. A vállalati kör jellemzése rendkívül nehézkes, hiszen megtalálhatjuk közöttük azokat a vállalkozókat, akik főfoglalkozásuk mellett végeznek különböző szolgáltatásokat, vélhetően csupán ,adó-optimalizálási” megfontolásokból (innen ered a csoport megnevezése is) létesítve az egész vállalkozást. De ide soroltuk mindazon kisvállalkozásokat is, amelyek már méretüknél fogva is, csekély gazdasági hatást gyakorolnak a környezetükre.

A csoport telephelyválasztását nem gazdasági tényezök határozzák meg - sokkal inkább a lakóhelyi szuburbanizációból vezethetô le a vállalkozások megtelepedése. Ahogyan ingatlanszakértók szoktak fogalmazni: az Érd-Veresegyház vonaltól északra fekvő települések ingatlanpiaci pozíciója tekinthető jónak, ezek a települé- 
sek tudják a magasabb státuszú fóvárosi lakosokat megszólítani, azokat, akiknek vannak vállalkozásai is. Ettől a képzeletbeli, de a valóságban erösen érzékelhető vonaltól délre sokkal alacsonyabb a beköltözö vállalkozások között a tercier szektorba tartozó cégek aránya (4. ábra) és meghatározó a termelö funkció.

$x x x$

A fenti csoportosítás meglehetősen önkényes, inkább csak a föbb típusokat ragadja meg, ám segítségével mégis könnyebben értelmezhetö ez a bonyolult társadalmigazdasági jelenség. A magyarországi helyzet sajátossága a gazdaságilag fejlett országokkal összevetve az, hogy összetorlódtak azok a technikai, technológia, szabályozási stb. hatások, amelyek befolyásolják a vállalkozások térbeli elhelyezkedését. Ebből adódóan hazánkban, de különösen a fơvárosi agglomerációban látványos alkalmazkodási folyamat indult el. A folyamat résztvevői markánsan eltérö szándékokkal kapcsolódnak be a gazdasági szuburbanizációs folyamatba. Az eltérỏ szándékok, célok hatására a folyamat markáns térbeli jellegzetességeket mutat, alapvetően formálva át a hosszú évtizedek során kialakult gazdasági szerkezetet.

\section{Irodalom}

Barta Gy. (2001) Az ipar szerkezetének térbeli változásai Magyarországon (1950-2000). Dialóg Campus, Budapest-Pécs.

Beauregard, R.A. (1995) Edge Cities: Peripheralizing the Center. - Urban Studies. 16. 708-721, o.

Bodenman, J.E. (1998) The Suburbanization of the Institutional Investment Advisory Industry: Metropolitan Philadelphia, 1983-1993. - The Professional Geographer. 1. 112-126. o.

Brennan, J.-Hill, E. (1999) Where are the jobs? Cities, suburbs, and the competition for employment. The Brookings Institution, Survey Series. November. 1-9. o.

Bryson, J.-Keeble, D.-Wood, P. (1993) The Creation, Location and Growth of Small Business Service Firms in the United Kingdom. - Service Industries Journal. 13, 118-131 o.

Carlino, G,A. (1998) Trends in Metropolitan Employment Growth. - Business Review. July-August. Federal Reserve Bank of Philadelphia. 13-22. o.

Carlzon, J. (1985) Lapitsd le a piramist. Zrínyi Nyomda, Budapest.

Cheshire, P.C.-Hay, D.G. (1989) Urban Problems in Western Europe. Unwin Hyman, London.

Coffey, W. (2000) The Geographies of Producer Services. - Urban Geography. 21. 170-183 o.

Cohen, N. (2000) Business Location Decision-making and the Cities: Bringing Companies Back. Working Paper, The Brookings Institution, Center on Urban and Metropolitan Policy, Washington DC.

Ewers, H.J.-Goddard, J.B.-Matzerath, H. (eds.) (1986) The Future of the Metropolis. Walter de Gruyter, Berlin-New York.

Ingram, G.K. (ed.) (1977) Residential Location and Urban Housing Markets. Ballinger Publishing Company, Cambridge.

Keeble, D.-Tyler, P. (1995) Enterprising Behaviour and the Urban-Rural Shift. - Urban Studies. 6. 975-997. 0.

Lang, R.E. (2000) Office Sprawl: The Evolving Geography of Business. The Brookings Institution, Center on Urban and Metropolitan Policy, Washinton DC.

Lengyel, I. (1994) A telephelyválasztás, - Rechnitzer J. (szerk.) Fejezetek a regionális gazdaságtan tanulmányozásához. MTA RKK, Györ-Pécs. 35-68. o.

Lengyel I. (2000) A regionális versenyképességröl. - Közgazdasági Szemle. 12. 962-987. o.

Lowe, M.-Wrigley, N. (2000) Retail and the Urban. - Urban Geography. 21. 640-653. o.

Meardon, S.J. (2001) Modeling Agglomeration and Dispersion in City and Country: Gunnar Myrdal, Francois Perroux, and the New Economic Geography. - The American Journal of Economics and Sociology. 1. 25-57. o. 
Metropolitan Decentralization in Chicago. (2001) Chicago Case Study Working Group of the Great Cities Institute, College of Urban Planning and Public Affairs, University of Illinois at Chicago, UIC.

Mullin, R. (1996) Tactical Site Selection. - Journal of Business Strategy. May-June. 27-32. o.

Ottaviano, G.-Puga, D. (1997) Agglomeration in the Glbbal Economy: A Survey of the "New Economic Geography". Centre for Economic Performance. Discussion Paper. 356.

Porter, M.E. (1994) The Role of Location in Competition. - Journal of Economics of Business. 1. 35-39. o.

Shafer, T. (1977) Urban Growth and Economics. Reston Publishing Company Inc., Reston.

Schmenner, R.W. (1979) Look Beyond the Obvious in Plant Location. - Harvard Business Review. January-February. 126-132. o.

Schreiber, A.F.-Gatons, P.K.-Clemmer, R.B. (eds.) (1976) Economics of Urban Problems. Houghton Mifflin Company, Company.

Tímár J.-Váradi M.M. (2000) A szuburbanizáció egyenlőtlen fejlődése az 1990-es évek Magyarországán. -Horváth Gy.-Rechnitzer J. (szerk.) Magyarország terilleti szerkezete és folyamatai az ezredfordulón. MTA RKK, Pécs. 153-175. o.

Willoughby, K. (2000) Building Internationally Competitive Technology Regions: The Industrial-LocationFactors Approach and the Local-Technological-Milieux Approach. - Journal of International and Area Studies. 2. 1-36. o.

Wood, P. (2001) Regional Innovation and Business Services. Előadás. 16. May. Malone House, Belfast.

\section{ADDITIONS TO THE QUESTION OF ECONOMIC SUBUR- BANISATION}

\section{BÁLINT KOÓS}

After the political-economic transition in Hungary the strict rules of the market economy enforced a rapid adaptation to these new conditions. One aspect of this adaptation is the reexamination of the firms' location. In consequence of this relocation the preceding high (urban) concentration of the economic activity has been reducing since the relocating firms prefer suburban location to rural or urban sites. 